\title{
An Archaeological Survey of the New Braunfels Little League Project, Comal County, Texas
}

John W. Arnn III

Center for Archaeological Research

Follow this and additional works at: https://scholarworks.sfasu.edu/ita

Part of the American Material Culture Commons, Archaeological Anthropology Commons, Environmental Studies Commons, Other American Studies Commons, Other Arts and Humanities Commons, Other History of Art, Architecture, and Archaeology Commons, and the United States History Commons

Tell us how this article helped you.

This Article is brought to you for free and open access by the Center for Regional Heritage Research at SFA ScholarWorks. It has been accepted for inclusion in Index of Texas Archaeology: Open Access Gray Literature from the Lone Star State by an authorized editor of SFA ScholarWorks. For more information, please contact cdsscholarworks@sfasu.edu. 


\section{An Archaeological Survey of the New Braunfels Little League Project, Comal County, Texas}

\section{Creative Commons License}

\section{(c) (1) \&}

This work is licensed under a Creative Commons Attribution-NonCommercial 4.0 International License 


\title{
An Archaeological Survey of the New Braunfels Little League Project, Comal County, Texas
}

\author{
John W. Arnn, III \\ Robert J. Hard and C. Britt Bousman \\ Prinicipal Investigators
}

Texas Antiquities Permit No. 1791

(C) copyright 1998

Center for Archaeological Research

The University of Texas at San Antonio

Archaeological Survey Report, No. 271 
The following information is provided in accordance with the General Rules of Practice and Procedure, Chapter 41.11 (Investigative Reports), Texas Antiquities Committee:

1. Type of investigation: Survey

2. Project name: New Braunfels Little League

3. County: Comal

4. Principal investigators: Robert J. Hard and C. Britt Bousman

5. Name and location of sponsoring agency: City of New Braunfels, P.O. Box 311747, New Braunfels, Texas 78130

6. Texas Antiquities Permit No.: 1791

7. Published by the Center for Archaeological Research, The University of Texas at San Antonio, $6900 \mathrm{~N}$. Loop 1604 W., San Antonio, Texas 78249-0658, 1998

A list of publications offered by the Center for Archaeological Research is available. Call (210) 458-4378; write to the Center for Archaeological Research, The University of Texas at San Antonio, 6900 N. Loop 1604 W., San Antonio, Texas 78249-0658; e-mail to car@lonestar.utsa.edu; or visit CAR's web site at http://www.csbs.utsa.edu/research/car. 


\begin{abstract}
In February 1997, the Center for Archaeological Research of The University of Texas at San Antonio was contracted by the city of New Braunfels to conduct an archaeological investigation of an area to be impacted by the proposed construction of Little League baseball fields. CAR staff conducted a pedestrian survey of the project area along the Dry Comal Creek and monitored backhoe trenching operations. Two sites were recorded and assigned trinomials: Site 41CM220 lies on an active floodplain and probably represents an open prehistoric campsite with a Late Paleoindian period component. The site is in a previously disturbed setting and no additional investigations are recommended. Site 41CM219 lies on the adjacent hillside and has dense concentrations of historic and prehistoric artifacts. There is a historic stone wall bounding one side of the site, and one course of dressed field stones arranged in a rectangle reminiscent of a small family cemetery plot is located in another part of the site. The historic artifacts are consistent with ceramics associated with the early European - primarily German-settlement of the area. 41CM219 is outside the planned impact area. CAR recommends that any future impacts to the site be preceded by archival research and archaeological testing to determine the site's significance.
\end{abstract}




\section{Contents}

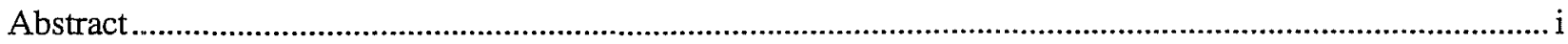

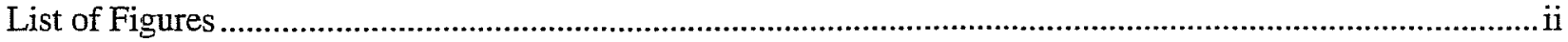

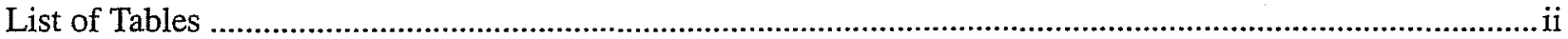

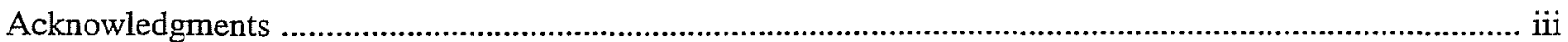

Introduction

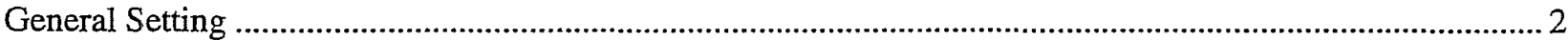

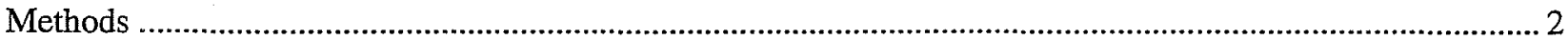

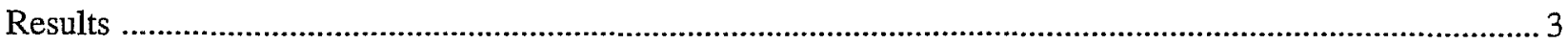

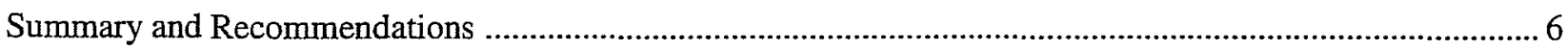

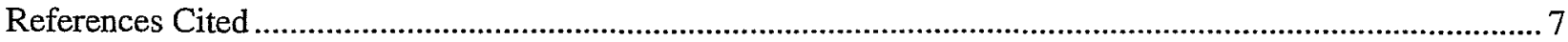

\section{Figures}

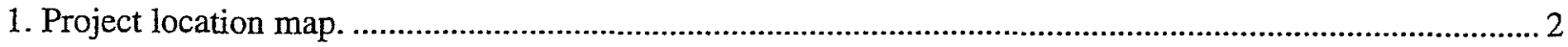

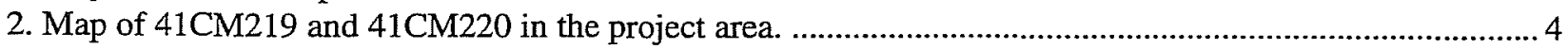

\section{Tables}

1. Geological Profile Descriptions 


\section{Acknowledgments}

This project would not have been possible without the generous logistical support, assistance, and advice of the city of New Braunfels. Staff members of the City Engineer's office, administered by Clarence Bolner, deserves particular attention for their support and assistance. In addition, I would like to thank Kimberly Kvernes for her assistance in the fieldwork portion of this investigation and Britt Bousman for supplying the geologic data for this report. Finally, I would like to thank Bruce Moses for his superb drafting abilities and Marcie Renner for her excellent editorial skills in assembling this publication. 



\section{Introduction}

In February 1997, the Center for Archaeological Research (CAR) of The University of Texas at San Antonio was contracted by the city of New Braunfels to conduct an archaeological survey of the area to be impacted by the proposed construction of eight Little League baseball fields, a concession stand, and restrooms. The project area is located approximately $1.5 \mathrm{~km}$ west of the town center on the outskirts of New Braunfels, Comal County, Texas (Figure 1). The planned construction will impact approximately 16 acres of the 43 acre plot of land owned by the city of New Braunfels. These impacts will include primarily above ground and shallow disturbances to create eight baseball fields. The limited subsurface impacts will include the installation of light poles and underground utilities to service the concession stand and restrooms. The maximum depth of these impacts will be approximately two meters, except in the case of a sewer line connection near Loop 337 which will be approximately $3.5 \mathrm{~m}$ deep. The exact location of the impacts and the final architectural plans for the project were not known at the time the archaeological survey was conducted.

The project area was first titled by Juan de Veramendi in November 1831 (Fey 1994:236). It remained in the Veramendi family until March 1845 when Prince Carl of Solms-Braunfels, the first Commissioner-General of the Society for the Protection of German Immigrants in Texas, purchased the property for colonization

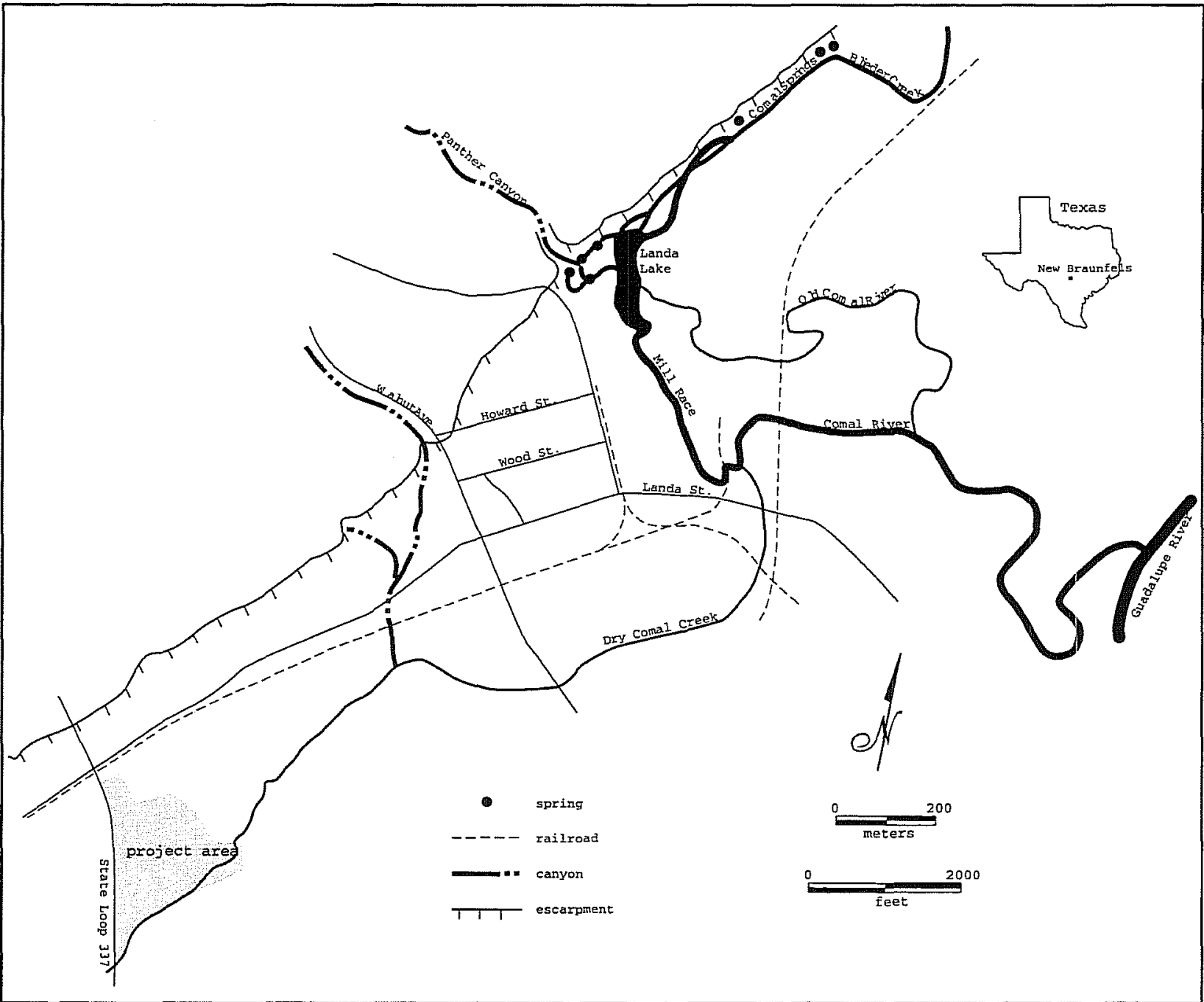

Figure 1. Project location map. 
(Haas 1968: 22). John O. Meusebach was granted the property by the German Emigration Company in July 1847 (Comal County Deed Records Vol. A 194-195). From Meusebach, the property passed through a number of hands until it was acquired by the city of New Braunfels in 1995. According to local informants, the project area has been a hay field for at least the last 20 years.

The archaeological survey was conducted by the author and Kimberly Kvernes. Robert J. Hard was the principal investigator, and C. Britt Bousman was the co-principal investigator. Because the planned construction project involves property and funding from the city of New Braunfels, a political subdivision of the state of Texas, an archaeological survey was required under the Texas Antiquities Code (Texas Natural Resources Code, Title 9, Chapter 191). The survey was conducted under Antiquities Permit number 1791 issued by the Texas Historical Commission.

\section{General Setting}

The project area is located on the western edge of New Braunfels off the east side of Loop 337 along the Dry Comal Creek. It is bounded on the southeast by the Dry Comal and on the northeast by a tributary of the Dry Comal. It is bounded on the west by Loop 337 . The project area can be divided into two distinct geographic areas: an active floodplain zone and an upland zone. The active floodplain is a recently plowed, flat, grass-covered meadow, its edges marked by trees growing along the drainages. The upland area occupies a small hill and, according to flood insurance maps, is out of both the 100- and 500-year flood zones (Flood Insurance Rate Map, 1991, City of New Braunfels, Comal and Guadalupe Counties, Community-Panel Number 4854930005 D, National Flood Insurance Program, Federal Emergency Management Agency [FEMA]).

The entire site lies less than $1.5 \mathrm{~km}$ from the Comal Springs and less than $500 \mathrm{~m}$ from the Balcones Escarpment. The Comal Springs represent an abundant and reliable water source and are characteristic of several large springs found along the base of the Balcones Escarpment from Waco to Del Rio (Brune 1981:129). The springs are the result of ground water percolating down through the Lower Cretaceous limestones of the Edwards Aquifer and rising along cracks and fissures in the Balcones Fault Zone at the base of the Balcones Escarpment.

The escarpment marks the convergence of the Edwards Plateau to the west and the Blackland Prairie to the east. This area is an ecotone in which a wide variety of plant and animal species which are normally restricted to either the Edwards Plateau or the Blackland Prairie are found (Diamond et al. 1987).

The rich environment described above provided an abundant and varied resource base for both prehistoric and historic peoples. Early historic accounts remark on the numbers of native peoples and the suitability of the area for colonization (Brune 1981:129; Roemer 1935). New Braunfels is one of the earliest German settlements in Texas. However, recent archaeological investigations have determined that this area also has a long and rich prehistoric heritage. Previous archaeological investigations have determined that surface and buried deposits of burned rocks, mussel shell, and lithic artifacts occur with high frequency throughout much of New Braunfels and tend to be concentrated close to springs and along drainages (Arnn 1997a, 1997b, 1997c, 1997d; Bailey 1986; Denton 1986, 1987; Espey, Huston, and Associates 1992, 1993; Jackson et al. 1936; Potter 1989; Smith 1985).

\section{Methods}

\section{Pedestrian Survey}

A pedestrian survey was conducted by two CAR staff members on the active floodplain and the adjacent hill. Prehistoric and historic artifacts were collected. Artifacts were collected according to their geographic location, and artifacts found on the floodplain were kept separate from those found on the hill. 


\section{Backhoe Trenches}

Although the exact location of the subsurface impacts associated with the planned construction had not been determined at the time the archaeological survey was conducted, four backhoe trenches (BHT) were excavated in areas approximating the location of the concession stand, restrooms, and light poles. Each trench was approximately four meters long and two meters deep. These excavations were monitored, and soil profiles were examined by CAR staff for cultural features or artifacts.

\section{Artifact Classification}

All diagnostic artifacts were compared to the typological definitions in Turner and Hester (1993). The temporal assignments of Turner and Hester (1993) were used as well. Nondiagnostic artifacts were classified into the following categories: platform or nonplatform bearing flakes, shatter, cores, unifaces, bifaces, heat-damaged chert (HDC), fire-cracked rock (FCR), and mussel shell (see Whitaker 1994 for a discussion of terms).

\section{Results}

\section{Geological Profiles}

Two backhoe trench profiles were excavated and described at site 41CM220 (Table 1). BHT 1 exposed $155 \mathrm{~cm}$ of alluvial sediments. The upper seven centimeters were disturbed and classified as an Ap horizon. Below this was a truncated $B$ horizon that had formed in fine-grained alluvial deposits. One prehistoric artifact was observed at $35 \mathrm{~cm}$ below the surface, but it was tilted vertically and appeared to have fallen down a pedogenic crack. No other artifacts were observed below the surface although a light scatter was present on the surface.

The profile in BHT 2 was very similar, with a disturbed Ap horizon in the upper seven centimeters covering a truncated $\mathrm{B}$ horizon below. In the $\mathrm{B}$ horizon a burned rock fragment was observed at $20 \mathrm{~cm}$ below the surface, but it is unlikely that it was in situ. In both profiles it appears that the upper surface was eroded and A horizon material transported off site. Rare archaeological materials appear to have fallen down pedogenic cracks and were not in situ.

\section{Survey}

The pedestrian survey and subsurface testing confirmed the initial conclusion that the floodplain area had been previously disturbed by years of agriculture use. The plow zone extended to a depth of approximately $50 \mathrm{~cm}$ in the four backhoe trenches. The upland part of the property, however, had not been plowed, but it lies outside the proposed impact area.

Essentially the entire floodplain section of the project area was disturbed by recent agricultural use. Along the edges of the creek was a great deal of small to large fire-cracked rock that does not appear to be an in situ feature. It is possible that this is what remains of burned rock features that were removed when the area was cleared for farming. The likelihood of encountering intact cultural features on the floodplain is minimal at best. If any cultural features are indeed present, they are at a greater depth than the proposed impact of the construction project.

Forty artifacts were collected within the project area. Of these, 36 were prehistoric lithic artifacts and four were historic artifacts. Historic artifacts were found only on the upland location, whereas prehistoric artifacts occurred throughout the project area. Two archaeological sites were recorded in the project area: an upland site (41CM219) and an active floodplain site (41CM220) (Figure 2).

\section{Site Descriptions}

\section{CM219}

Site 41CM219 encompasses virtually the entire hill and covers approximately 10,000 square meters. It is bounded by Loop 337 on the west, and drainages on the southeast and north sides. Two features are present at the site. A stone wall lies along the south side of the northern drainage, and several stones arranged in a 
This page has been

redacted because it

contains restricted

information. 
Table 1. Geological Profile Descriptions

\begin{tabular}{|c|c|c|}
\hline Zone & $\begin{array}{l}\text { Depth } \\
\text { (cm) }\end{array}$ & Description \\
\hline \multicolumn{3}{|r|}{ Profile 1} \\
\hline 1 & $0-7$ & $\begin{array}{l}\text { Dark brown (10YR 3/3) loam, loose crumb structure, abrupt smooth low er } \\
\text { boundary, Ap horizon. }\end{array}$ \\
\hline 2 & $7-50$ & $\begin{array}{l}\text { Dark brown (10YR } 3 / 5) \text { clay loam, moderate crumb structure, clay films on ped } \\
\text { faces, common snail shells, few } 1-5 \mathrm{~cm} \text { burrows, few fine faint red dish brown } \\
\text { ( } 2.5 \mathrm{YR} 4 / 4 \text { ) mottles, chert flake on edge at } 35 \mathrm{~cm} \text {, gradual smooth lower } \\
\text { boundary, B } 1 \text { horizon. }\end{array}$ \\
\hline 3 & $50-95$ & $\begin{array}{l}\text { Dark brown clay loam, medium weak subangular blocky structure, with } \\
\text { common medium distinct very dark grayish brown }(10 \mathrm{YR} 3 / 2) \text { mottles, } \\
\text { common fine faint strong brown }(7.5 \mathrm{YR} 4 / 6) \text { mottles, few small insect-size } \\
\text { burrows, common snail shell, few charcoal fragments, few small manganese } \\
\text { nodules, gradual smooth lower boundary, B2 horizon. }\end{array}$ \\
\hline 4 & $95-155+$ & $\begin{array}{l}\text { Brown ( } 7.5 \mathrm{YR} 4 / 4) \text { to strong brown }(7.5 \mathrm{YR} 4 / 6) \text { clay loam, fine medium } \\
\text { subangular blocky structure, clay films on ped faces, few to common small } \\
\text { calcium carbonate nodules that increase in frequency down profile, few snail } \\
\text { shells, few charcoal fragments, common dark brown }(10 \mathrm{YR} 3 / 3) \text { in sectburrows, } \\
\text { lower boundary not observed., B } 3 \text { horizon }\end{array}$ \\
\hline \multicolumn{3}{|r|}{ Profile 2} \\
\hline 1 & $0-7$ & $\begin{array}{l}\text { Dark brow n (10YR 3/3) loam, loose, crumb structure, few snail shells, rootlets, } \\
\text { very few small pebbles, abrupt smooth low er boundary, Ap horizon. }\end{array}$ \\
\hline 2 & $7-17$ & $\begin{array}{l}\text { Dark brown ( } 7.5 \text { YR } 3 / 4) \text { clay loam, medium weak crumb structure, clay films } \\
\text { on ped faces, common snail shell, rootlets, abrupt smooth lower boun dary, B } 1 \\
\text { horizon. }\end{array}$ \\
\hline 3 & $17-65$ & $\begin{array}{l}\text { Dark brown (10YR } 3 / 3 \text { ) clay loam, friable, weak moderate fine granular } \\
\text { structure, clay films on ped faces, common snail shells, rootlets, bumed rock at } \\
20 \mathrm{~cm} \text {, gradual smooth lower boundary, B3 horizon. }\end{array}$ \\
\hline 4 & $65-115+$ & $\begin{array}{l}\text { Dark reddish brown (5 YR 3/3) firm clay loam, medium moderate subangular } \\
\text { blocky structure, clay films on ped faces, rootlets, few snail shells, calcium } \\
\text { carbonate filaments, lower boundary not observed, B3 horizon. }\end{array}$ \\
\hline
\end{tabular}

rectangle are found on the peak of the hill (Figure 2). The stone wall is stacked and is similar to other historic stone walls found throughout the German Hill Country. The rectangular arrangement of stones is approximately $4.5 \mathrm{~m}$ in length, $3 \mathrm{~m}$ wide at the west end, and $2.6 \mathrm{~m}$ wide on the east end. The feature is oriented north/south, and is composed of one course of dressed stones lying on the surface of the ground. This investigation revealed no historic record of either of these features.

A pedestrian survey of this site produced a total of 21 artifacts. Seventeen of these artifacts were prehistoric lithic artifacts and included 12 bifaces, four platform flakes, and one nonplatform flake. The historic artifacts included one piece of Oriental porcelain, one sherd of transfer ware, the base of a glass beer mug, and one fragment of blue glass.

\section{$41 \mathrm{CM} 220$}

Site 41CM220 covers approximately 50,000 square meters and is bounded on the west by Loop 337, on the northwest and northeast by small drainages, and 
on the southeast by the Dry Comal Creek. No features were observed and all artifacts, with the exception of one flake, were found on the surface. A pedestrian survey of the floodplain site located 19 prehistoric artifacts including 10 bifaces, two cores, five platform flakes, and two nonplatform flakes. One of the bifaces bears a strong resemblance to an Angostura projectile point and suggests a possible Late Paleoindian component. However, the floodplain has been actively farmed for many years and the context of all surface finds is questionable.

The backhoe trench excavations in site 41CM220 produced one nonplatform flake in BHT A. This flake was found within $45 \mathrm{~cm}$ of the surface in the plow zone. The observed soil profiles indicated that the site is on an alluvial terrace that has weathered to form a dark-brown A horizon overlying a reddish-brown B horizon. The context in which the flake was found should be considered disturbed.

\section{Summary and Recommendations}

The upland site, 41CM219, is distinctive in that it is one of the few locations in the area located well above the floodplain. According to FEMA maps, this hill is above both the 100- and 500-year flood boundaries. Consequently, the hilltop would have made an excellent site for prehistoric camps and later homesteads. The artifacts collected suggest these types of sites. While the archival search did not provide evidence of stone structures or cemeteries and the survey revealed no sign of a house or building, the location, size, and configuration of the stone rectangle suggests a small family cemetery plot. In addition, stacked stone walls are ubiquitous in the German Hill Country and generally denote field and pasture boundaries (Haas 1968:46). In this particular case, the wall lies along the edge of a drainage and might also have been erected to stabilize the hillside. This site is outside the proposed impact area of the little league field construction project. We recommend that any further development of 41CM219 be preceded by additional archival research to determine the property history and archaeological testing to determine the nature, extent, and significance of the cultural materials present.

Even though a late Paleoindian artifact was recovered from site 41CM220, the disturbance on the floodplain is such that the presence of intact features is unlikely. Therefore, no additional investigations are recommended at 41CM220. 


\section{References Cited}

Arnn, J. W., III

1997a Archaeological Investigations at the Landa Park Golf Course, New Braunfels, Texas. Archaeological Survey Report, No. 250. Center for Archaeological Research, The University of Texas at San Antonio.

1997b Archaeological Monitoring of a Sidewalk Construction Project in Landa Park, New Braunfels, Comal County, Texas. Archaeological Survey Report, No. 254. Center for Archaeological Research, The University of Texas at San Antonio.

1997c Archaeological Monitoring of a Parking Lot Construction Project in New Braunfels, Comal County, Texas. Archaeological Survey Report, No. 255. Center for Archaeological Research, The University of Texas at San Antonio.

1997d Archaeological Investigations at the Landa Park Golf Proshop in New Braunfels Comal County, Texas. Archaeological Survey Report, No. 256. Center for Archaeological Research, The University of Texas at San Antonio.

Bailey, G. L.

1986 Archaeological Investigations in Landa Park, City of New Braunfels, Comal County, Texas. Letter Report No. 330. Prewitt and Associates, Austin.

Brune, $\mathrm{G}$.

1981 Springs of Texas. Vol. 1. Branch-Smith, Fort Worth.

Denton, $\mathrm{M}$.

1986 Field notes, 41CM76. On file, Texas Historic Commission, Austin.

1987 Field notes, 41CM75. On file, Texas Historic Commission, Austin.

Diamond, D. D., D. H. Riskind, and S. L. Orzell

1987 A Framework for Plant Community Classification and Conservation in Texas. The Texas Journal of Science 39: 3:203-221.

Espey, Huston and Associates (EHA)

1992 A Cultural Resources Survey of the Landa Park to Krueger Canyon Road Transmission Line Rebuild Project Comal County, Texas. Espey Huston and Associates, Austin.

1993 Archaeological Monitoring and Testing of the Landa Park to Krueger Canyon Road Transmission Line Rebuild Project Comal County, Texas. Espey Huston and Associates, Austin.

Fey, E. A.

1994 New Braunfels: The First Founders. Eakin, Austin.

Haas, $\mathrm{O}$.

1968 The History of New Braunfels and Comal County, 1844-1946. Steck, Austin.

Jackson, A. T., J. E. Pearce, and A. M. Woolsey

1936 Notes on Fieldwork, H. C. Locke Farm, 1 Mile West of New Braunfels, Comal County, Texas. On file, Texas Archaeological Research Laboratory, The University of Texas at Austin.

Potter, D. R.

1989 Archaeological Testing at two Well Locations in New Braunfels, Comal County, Texas. Archaeological Survey Report, No. 187. Center for Archaeological Research, University of Texas at San Antonio. 
Roemer, F.

1935 Roemer's Texas. Texian Press, San Antonio.

Smith, $H$.

1985 An Assessment of Archaeological Resources in Landa and Cypress Bend Recreation Areas, New Braunfels, Texas. Manuscript on file. Texas Historical Commission, Austin.

Turner, E. S., and T. R. Hester

1993 A Field Guide to Stone Artifacts of Texas Indians. Second edition. Gulf, Houston.

Whitaker, J. C.

1994 Flintknapping, Making and Understanding Stone Tools. University of Texas Press, Austin. 